\title{
EMPIRICAL VERIFICATION OF THE OCCURRENCE OF LUCAS PARADOX IN THE REGION OF CENTRAL - EASTERN EUROPE
}

\section{Agata Maria Górniak}

\begin{abstract}
The purpose of this article is to study the occurrence of the Lucas paradox in the region of CentralEastern Europe. According to the research conducted by Robert Lucas (1990), the direction of the international capital flows is different than the neoclassical theory suggests. The capital does not flow from the richer, high-income economies to the poorer, but rather stays in those with the higher capital resources or flows to the other ones with similar level of GDP. The paper verifies whether the paradox appears in the region, in the way that it examines the impact of the GDP on the FDI inflows. Additionally, the study implements few basic models with factors that may potentially resolve the puzzle of the capital flows. The study method is based on panel data estimations, initially using pooled OLS, and subsequently using fixed or random effects models as appropriate. The examined economies are the member states of the European Union, from the region of Central-Eastern Europe, and the examined years are 2000-2018. Based on the literature, and the widely emphasized need for differentiating between the types of international capital flows, the article focus is on the foreign direct investment only, as they constitute large part of the whole global capital flows. Results of the research confirm the presence of the paradox in the region in the examined period. Even though the estimation of the additional models helps to remove the effects of the paradox for the region, it does not fully explain under which circumstances the neoclassical theory would be applicable. None of the applied models reverses the sign of the GDP variable to negative, keeping it statistically significant at the same time.
\end{abstract}

Keywords: International Economics, International Capital Flows, International Investment, Long-Term Capital Movements, Foreign Direct Investment.

JEL Class: E22, F21, F23.

\footnotetext{
* MsC in International Economic Relations (International Business), Economics PhD student, Kozminski University; https://orcid.org/0000-0002-1450-7537.
} 


\section{INTRODUCTION}

Foreign capital flows in the form of foreign direct investment (FDI) are currently considered as valuable, long term source of funding and development for the less developed economies. Therefore, studying factors that impact the value of the received capital flows has been of many researchers' interests. In one of his studies, Robert Lucas (1990) proposed a thesis that neoclassical theories on the capital flows do not reflect the reality of the foreign investment streams. After the author's publication, a wide debate has started with many researchers attempting to identify potential resolutions to the problem and discovering the variables which would possibly help to direct the capital flows to other countries. The study presented in the paper attempts to verify whether the paradox of the international capital flows described by Robert Lucas has occurred in the region of Central Eastern Europe in the recent years. Also, it verifies whether some basic variables, identified in other researchers' works as significant, have the power to reverse the paradox.

\section{LITERATURE REVIEW}

In his article from 1990, Robert Lucas noticed that despite the neoclassical models claiming that the direction of capital flow should be from the richer countries to the poorer ones, in reality the developed economies receive the majority of the investment. The capital, according to the neoclassical theory, should flow to the countries which have scarcity of the factors, being able to offer higher rate of return. The author provided possible explanations to the problem in his paper, however none of them fully resolved the puzzle. The initial proposed resolution of the paradox comprised of including to the specification the differences in the human capital, the other concerned potential "external benefits of human capital" (Lucas, 1990). Furthermore, the author examined the capital market imperfections, such as political risks, and the types of agreements appearing between the rich and the poorer countries (Lucas, 1990).

In the literature, in the context of research on the Lucas paradox, the studied factors are divided into two groups, the shortcomings of a model and those related to international financial markets, as suggested by author himself (Lucas, 1990). The first group includes factors such as missing production and factors and others that affect productivity. The second group includes information asymmetry and investment risk (Lucas, 1990; Alfaro et al., 2005; van Wijnbergen and Franken, 2010). The cross-section of potentially reversing variables is large. In the context of factors influencing changes in the production structure, most often mentioned are, among others, education, institutional factors, and differences in 
technologies (Alfaro et al., 2005). Factors related to financial market failure are information asymmetry (Kinda, 2010), risk (van Wijnbergen and Franken, 2010: 4) or market capitalisation, which is described by the degree of development of financial markets (van Wijnbergen and Franken, 2010). The studies dealing with the Lucas paradox, relied on such a selection of internal and external factors related to the studied economy as to change the sign of the per capita income variable (the variable indicating the origin of the Lucas paradox) to negative in the studied model (van Wijnbergen and Franken, 2010).

The 2005 study by Alfaro, Kalemli-Ozcana and Volosovych took into account many primary factors that ought to explain Lucas paradox, such as, for example, the quality of the institutions, the number of years spent at school, the geographical distance from the capital city to other capitals, restrictions on the mobility of capital. Moreover, additional factors to test the model were used: CPI, openness - trade development, tax levels for companies, investment incentives for FDI, restrictions on the FDI inflows. The study proved that it was the low quality of institutions, that accounted for for the low level of capital inflows to developing countries. According to the authors, institutions were the factor most fully explaining and influencing the occurrence of the Lucas paradox in the long term (the study covered the period from 1970 to 2000). Among the institutional factors, the authors mentioned, for example: private property rights, corruption, stability, bureaucracy (Alfaro et al., 2005).

The results were consistent with those obtained by other authors, using different research models, who also pointed to the significance of the institutional variable, the improvement of which may have a positive impact on the increase in capital inflow (Schularick and Steger, 2008). In the case of studies that duplicate and correct the assumptions of the model presented by Alfaro, Kalemli-Ozcan and Volosovych, the institutional variable was indicated as significant, but was not the factor resolving the paradox of the direction of capital flows. Human capital and the degree of openness to foreign countries (development of foreign trade) were recognized as relevant for encouraging higher investment flows to the host state as well. Significantly, none of those factors fully resolved the paradox (Akhtaruzzaman et al., 2016).

Also, the study conducted by Bilal Keskinsoy (Keskinsoy, 2017) utilised the examination of Alfaro, Kalemli-Ozcan and Volosovych and provided findings which bring new perspective to the field. The author tested the assumption that there was a bias of the developed countries over the developing ones in the model, which resulted in overestimation of the role of the institutional quality. The obtained results of his study suggested that in the long run, the paradox was not fully explained for the sample of developing countries that were included in the model (Keskinsoy, 2017). 
Van Wijnbergen and Franken also included a number of explanatory variables from different categories in their developing countries study. The variables they included in their model are market size, public debt, openness (globalisation), natural resources, financial development, human capital (its quality, measured by education), quality of institutions, macroeconomic stability. In total, researchers used twenty-four explanatory variables in their regression analysis. The obtained results indicated a positive relationship between incoming capital and GDP (the variable determining the occurrence of the Lucas paradox), the correlation disappeared (becomes statistically insignificant) when specific country effects were included in the model. The results did not confirm or reject a positive relationship with the human capital factor and institutions (the variables are statistically insignificant). However, there was a positive correlation with the variable determining the level of democratisation of the country. The authors also concluded in their considerations that there was a great need to distinguish between different types of capital flows. They argue that the factors influencing the three types of capital flows (FDI, debt and portfolio investment) were significantly different (van Wijnbergen and Franken, 2010).

\section{EMPIRICAL VERIFICATION}

\subsection{The purpose of the study}

The main objective of the study is to verify the occurrence of the Lucas paradox in FDI inflows into the countries of the Central and Eastern Europe, and the impact of some basic factors described as explaining the paradox. On the basis of literature, these simple models studied included factors defined as justifying the direction of capital flows from highly developed countries to those at a similar level, and not, as the neoclassical theory would suggest, to developing countries. Factors include only a group of internal factors for the countries surveyed. What is more, only capital flows in the form of FDI are included in the study, not all of the types of the capital flows. The separation and distinction between the types of capital flows and their relationship to GDP will subsequently allow for a more detailed analysis of the results obtained. Due to the completely different nature of the components of international capital flows, such an analysis could not be carried out without first distinguishing them. This need has been recognised by some authors of previous studies (van Wijnbergen and Franken, 2010).

In this paper, two groups of models are distinguished: the first one to investigate the occurrence of the Lucas paradox in the studied group of economies (model 1 in both pooled OLS and RE/FE estimations), and the second one to investigate the factors influencing the occurrence of the paradox. In the first group 
of models, the impact of GDP on FDI inflows is examined, while the second group of models is an extension of the basic Lucas paradox model with some additional basic explanatory variables. Additionally, the subsequent models are estimated several times interchangeably using explanatory variables to further investigate the impact of particular factors on capital inflows in the region, in the same way as other authors conducted their studies. Each of the additional explanatory variables is separately included in the model in order to check whether the particular factor impacts the significance and the sign of the variable GDP, which would indicate the reversal of the paradox.

\subsection{Data and variables selection}

The study uses panel data for a group of ten European Union countries, from the Central and Eastern Europe region, from the 2004 and 2007 enlargements. The full list of countries is as follows: Bulgaria, Czech, Estonia, Hungary, Latvia, Lithuania, Poland, Slovakia, Slovenia, Romania. The examined period consists of the years 2000-2018. The collected statistical data is derived from publicly available databases of international organisations, such as the World Bank, United Nations and UNCTAD and others. All of the variables are described in detail below.

The following dependent variable is introduced in the models:

- FDI inflows per capita, expressed in current prices, in US dollars (UNCTAD, 2020);

The following independent variables are introduced in the models:

- GDP per capita, the data comes from the World Bank's database, the values are expressed in current US\$ (World Bank, 2020a). The data is transformed into logarithms;

- Regulatory quality index which measures the quality of the existing regulations, created and published by the World Bank. This indicator assesses the capability of the government to propose and implement business friendly and effective legal solutions which allow for the business development. The value range is between 0 and 100 , with 100 being highest. For this variable, the data from year 2001 is missing (World Bank, 2020b);

- Government effectiveness index, created and published by World Bank, is a measure of the quality of the policies implemented, but also the reliability of the government, degree of freedom of the civil service from political bias and other similar factors. The value range is between 0 and 100, with 100 being highest. For this variable, the data from the year 2001 is missing (World Bank, 2020d); 
- Economic openness variable (also referred to as trade development, globalization or openness index) is foreign trade (exports and imports of goods and services) expressed as a percentage of GDP, the data comes from the World Bank's database (World Bank, 2020c). The data is transformed into logarithms;

- Education variable which the ratio of the labor force with advanced education to the total working age population. The data comes from World Bank (World Bank, 2021).

The expected result is a positive and statistically significant correlation between the logarithm of GDP per capita and FDI inflows per capita, which indicates the presence of the Lucas paradox. Negative and statistically significant dependency means that GDP per capita growth results in a decrease in FDI inflows, and that the capital flows to less developed countries. Therefore, in such a case, the neoclassical theory would be justified (van Wijnbergen and Franken, 2010). When analysing the factors potentially removing the paradox, the expected outcome is to reveal which variable changes the significance of the variable GDP (makes it insignificant) as in Alfaro (Alfaro et al., 2005).

On a side note, it may be also mentioned, that there are some discrepancies in the literature in regard to some of the assumed results. As an example, in most of the studies, openness and globalisation of the economy are combined with an increase in the flow of capital, as in van Wijnbergen and Franken (2010). However, there are studies in which researchers indicate a negative relationship between openness of the economy and FDI inflows (Hausmann and Fernandez-Arias, 2000).

Table 1. Descriptive statistics for the applied variables

\begin{tabular}{|c|c|c|c|c|c|}
\hline Variable & Average & Median & St. dev. & Min & Max \\
\hline FDI inflow per capita (FDI) & 420,8 & 341,3 & 397,5 & -1512 & 2065 \\
\hline GDP per capita (GDP) & 12374 & 12586 & 6018 & 1621 & 27483 \\
\hline $\begin{array}{c}\text { Regulatory quality index } \\
\text { (REG) }\end{array}$ & 78,27 & 78,75 & 7,397 & 48,72 & 93,27 \\
\hline $\begin{array}{c}\text { Government effectiveness } \\
\text { index (GOV) }\end{array}$ & 71,88 & 74,81 & 10,58 & 42,56 & 85,58 \\
\hline $\begin{array}{c}\text { Labour force with advanced } \\
\text { education as \% of total } \\
\text { working (EDU) }\end{array}$ & 79,02 & 79,77 & 3,403 & 72,38 & 86,32 \\
\hline Economic openness (TRA) & 119,8 & 123,4 & 33,09 & 48,52 & 190,2 \\
\hline
\end{tabular}

Source: own study. 
On the basis of the table 1 with descriptive statistics, it can be concluded that although the examined countries come from one region, in the examined group there are quite large differences in the examined variables. Particularly large differences are visible in the GDP variable, in minimal and maximal values of the variable, and the globalization/openness index (trade development) values. This may indicate somehow differentiated level of economic development in the surveyed group over the years or volatility of the applied variables.

Table 2. Correlation matrix for the applied variables

\begin{tabular}{|c|c|c|c|c|c|c|}
\hline & FDI & GDP log & REG & GOV & EDU & TRA log \\
\hline FDI & 1,000 & 0,2110 & 0,3379 & 0,1956 & 0,0905 & 0,2358 \\
\hline GDP log & & 1,000 & 0,5289 & 0,5854 & 0,0984 & 0,6717 \\
\hline REG & & & 1,000 & 0,7520 & 0,2631 & 0,5664 \\
\hline GOV & & & & 1,000 & 0,1366 & 0,6451 \\
\hline EDU & & & & & 1,000 & $-0,2251$ \\
\hline TRA log & & & & & & 1,000 \\
\hline
\end{tabular}

Source: own study

The above table 2 presents correlation matrix for the applied variables. The highest correlation occurs between governmental efficiency index and regulatory index, which perhaps derives from the nature of the variables. This has been taken into account and the variables are not applied together in one model.

\subsection{Method}

The models are initially estimated using the pooled OLS (ordinary least squares) method for each of the models presented in the paper. Robust standard errors are used in the models. Additionally, three tests: F statistics test, Breusch-Pagan and Hausman, have been conducted. The tests help to choose the relevant estimation methods for the models. Based on the tests results, the decision on the choice between random effects (RE), fixed effects (FE) or pooled OLS has been made. Accordingly, RE and FE estimations have been conducted for the robustness of the method. 


\subsection{Results}

The table 3 below presents the results of the basic pooled OLS estimations. The table contains also information on the number of observations included in each model, which may slightly differ due to data limitations, as well as $\mathrm{R}^{2}$ and adjusted $\mathrm{R}^{2}$ values, as expected, quite low, due to the models' simplicity.

Table 3. Results of the OLS estimations

\begin{tabular}{|c|c|c|c|c|c|c|}
\hline & \multicolumn{6}{|c|}{$\begin{array}{c}\text { Pooled OLS estimation, years } 2000 \text { - 2018, panel of } 10 \text { economies of CEE } \\
\text { Dependent variable: FDI } \\
\text { Robust standard errors applied in all models }\end{array}$} \\
\hline Variables: & [1] & [2] & [3] & [4] & [5] & {$[6]$} \\
\hline GDP log & $\begin{array}{l}136,59 * \\
{[64,04]}\end{array}$ & $\begin{array}{c}0,52 \\
{[57,56]}\end{array}$ & $\begin{array}{c}68,94 \\
{[57,51]}\end{array}$ & $\begin{array}{l}132,11^{*} \\
{[64,97]}\end{array}$ & $\begin{array}{c}62,06 \\
{[69,56]}\end{array}$ & $\begin{array}{c}-21,03 \\
{[100,71]}\end{array}$ \\
\hline REG & & $\begin{array}{c}18,44 * * \\
{[7,61]}\end{array}$ & & & & $\begin{array}{l}16,98^{*} \\
{[8,11]}\end{array}$ \\
\hline GOV & & & $\begin{array}{c}5,27 \\
{[5,28]}\end{array}$ & & & \\
\hline$\overline{\mathrm{EDU}}$ & & & & $\begin{array}{c}8,22 \\
{[15,75]}\end{array}$ & & $\begin{array}{c}3,17 \\
{[18,44]}\end{array}$ \\
\hline TRA log & & & & & $\begin{array}{c}224,43 \\
{[138,36]}\end{array}$ & $\begin{array}{c}85,62 \\
{[225,49]}\end{array}$ \\
\hline Cons & $\begin{array}{c}-845,18 \\
{[561,94]}\end{array}$ & $\begin{array}{c}-1016,93 \\
{[646,49]}\end{array}$ & $\begin{array}{r}-590,03 \\
{[554,75]}\end{array}$ & $\begin{array}{l}-1453,36 \\
{[1385,88]}\end{array}$ & $\begin{array}{c}-1218,94^{*} \\
{[611,54]}\end{array}$ & $\begin{array}{l}-1360,15 \\
{[1495,40]}\end{array}$ \\
\hline No. of obs. & 190 & 180 & 180 & 190 & 190 & 180 \\
\hline $\mathrm{R}^{2}$ & 0,045 & 0,114 & 0,045 & 0,049 & 0,061 & 0,116 \\
\hline Adjusted $\mathrm{R}^{2}$ & 0,039 & 0,104 & 0,034 & 0,039 & 0,051 & 0,095 \\
\hline
\end{tabular}

Significance levels: $* * * 1 \%, * * 5 \%, * 10 \%$

Source: own study.

The most appropriate estimation methods chosen based on the tests are presented in the table 4, together with those tests results. The F statistics test has been used as a help to choose between pooled OLS and FE, the Breusch-Pagan test between pooled OLS and RE and the Hausman test between RE and FE. The applied tests indicate different appropriate estimation methods (RE, FE) for different models, which may be a result of different data structure. In most of the cases, in the simple models with just two explanatory variables, the differences between the countries in the panel may actually be significant enough to impact the dependent variable, therefore the choice of the random effects seems to be appropriate. Only for models 4 and 6 the suitable choice is the model with the fixed effects. 
Table 4. Choice of the estimation method based on test applied and presented in table 3

\begin{tabular}{|c|c|c|c|c|c|c|}
\hline Models: & {$[1]$} & {$[2]$} & {$[3]$} & {$[4]$} & {$[5]$} & {$[6]$} \\
\hline F statistics test & 0,000 & 0,001 & 0,000 & 0,000 & 0,000 & 0,000 \\
\hline $\begin{array}{c}\text { Breusch-Pagan } \\
\text { test }\end{array}$ & 0,000 & 0,000 & 0,000 & 0,000 & 0,000 & 0,000 \\
\hline Hausman test & 0,882 & 0,455 & 0,406 & 0,039 & 0,186 & 0,009 \\
\hline $\begin{array}{c}\text { RE/FE } \\
\text { applicable }\end{array}$ & $\mathrm{RE}$ & $\mathrm{RE}$ & $\mathrm{RE}$ & $\mathrm{FE}$ & $\mathrm{RE}$ & $\mathrm{FE}$ \\
\hline
\end{tabular}

Source: own study.

Table 5 below presents the results of the RE/FE estimations for the same set of models as in the case of the pooled OLS.

Table 5. Results of the RE/FE estimations

\begin{tabular}{|c|c|c|c|c|c|c|}
\hline \multirow[b]{2}{*}{ Variables: } & \multicolumn{6}{|c|}{$\begin{array}{c}\text { RE/FE estimations, years } 2000-2018 \text {, panel of } 10 \text { economies of CEE } \\
\text { Dependent variable: FDI } \\
\text { Robust standard errors applied in all models }\end{array}$} \\
\hline & [1] RE & [2] RE & [3] RE & [4] FE & [5[ RE & [6] FE \\
\hline GDP log & $\begin{array}{c}128,96^{* *} \\
{[51,60]}\end{array}$ & $\begin{array}{c}40,36 \\
{[69,38]}\end{array}$ & $\begin{array}{l}106,50^{*} \\
{[57,95]}\end{array}$ & $\begin{array}{c}118,70 * * \\
{[42,71]}\end{array}$ & $\begin{array}{l}145,79 * \\
{[87,96]}\end{array}$ & $\begin{array}{c}127,79 \\
{[189,30]}\end{array}$ \\
\hline REG & & $\begin{array}{c}13,70 * * \\
{[6,74]}\end{array}$ & & & & $\begin{array}{c}-7,69 \\
{[10,52]}\end{array}$ \\
\hline GOV & & & $\begin{array}{c}1,00 \\
{[6,97]}\end{array}$ & & & \\
\hline EDU & & & & $\begin{array}{c}55,20 * * * \\
{[12,10]} \\
\end{array}$ & & $\begin{array}{c}65,30 * * * \\
{[11,38]}\end{array}$ \\
\hline TRA log & & & & & $\begin{array}{c}-56,64 \\
{[192,34]}\end{array}$ & $\begin{array}{c}-2,30 \\
{[442,27]}\end{array}$ \\
\hline Cons & $\begin{array}{r}-774,47^{*} \\
{[448,99]} \\
\end{array}$ & $\begin{array}{c}-1017,88^{*} \\
{[536,22]} \\
\end{array}$ & $\begin{array}{r}-633,35 \\
{[576,51]} \\
\end{array}$ & $\begin{array}{c}-5041,48 * * * \\
{[1128,63]} \\
\end{array}$ & $\begin{array}{l}-661,80 \\
{[493,56]}\end{array}$ & $\begin{array}{l}5307,34 * * \\
{[1829,35]}\end{array}$ \\
\hline No. of obs. & 190 & 180 & 180 & 190 & 190 & 180 \\
\hline
\end{tabular}

Significance levels: $* * * 1 \%, * * 5 \%, * 10 \%$

Source: own study.

All of the estimates seem to give somehow consistent view on the problem. Firstly, this simple study proves the existence of the Lucas paradox in the CentralEastern European countries in the years 2000-2018. The variable GDP per capita in the first model [1] in both estimations (pooled OLS and RE), has positive sign and is statistically significant, therefore the assumption about the occurrence of the paradox in the region is correct. Consequently, it may be concluded that in the 
examined period any increase in the GDP per capita, resulted in the increased inflow of the FDI per capita.

Secondly, the models which include other variables may give some indication about the direction to be followed in order to solve the paradox for the examined region. The variable representing regulatory quality in the country, in both OLS and RE estimations, as well as in the summary models removes the significance from the GDP variable. In the OLS estimates, also the variable representing government effectiveness removes the significance from the GDP, nonetheless, in the RE model, GDP again becomes statistically significant on a low level. Economic openness/trade variable causes similar effects on the GDP as the government effectiveness. Nevertheless, in none of the estimations GDP becomes negative and statistically significant, which would support the application of the neoclassical theory.

\section{CONCLUSIONS}

This simple study confirmed the occurrence of the Lucas paradox in the region. Therefore, it can be stated that the inflow of FDI per capita for the region is related to the GDP level. Moreover, some variables presented in the simple estimations, such as trade, regulations and government effectiveness, have the capability to affect the GDP variable, and they seem to be relevant in the context of the Central and Eastern European economies and the international capital flows. Accordingly, the abovementioned examined basic factors, may serve as a starting point for the further research in a way that they reveal direction of the group of the factors to be studied on more advanced level, if a full resolution to the paradox is to be found. The results are consistent with the views of the other researchers, whose studies also emphasize the role of the institutions and their quality, among with other factors, such as openness of the economy, as those crucial in attracting FDI.

\section{BIBLIOGRAPHY}

Akhtaruzzaman, M., Hajzler, C. and Owen, P.D. (2016). Does institutional quality resolve the Lucas Paradox? University of Otago Economics Discussion Papers, 1611, pp. 1-37, https://ourarchive.otago.ac.nz/bitstream/handle/10523/7026/DP_1611.pdf?sequence=1\&isAll owed $=\mathrm{y}$ [Accessed 23.02.2021].

Alfaro, L., Kalemli-Ozcan, S. and Volosovych, V. (2005). Why doesn't capital flow from rich to poor countries? An empirical investigation. NBER Working Paper Series, 11901, pp. 1-67, https://www.nber.org/papers/w11901.pdf [Accessed 23.02.2021].

Hausmann, R. and Fernandez-Arias, E. (2000), Foreign Direct Investment: Good Cholesterol? Inter-American Development Bank, Working Papers, 417, pp. 1-46, https://www.econstor.eu/bitstream/10419/87989/1/idb-wp_417.pdf [Accessed 23.02.2021]. 
Keskinsoy, B. (2017), Lucas paradox in The Long Run. MPRA Working Papers, 78126, pp. 1-24, https://mpra.ub.uni-muenchen.de/78126/1/MPRA_paper_78126.pdf [Accessed 23.02.2021].

Kinda, T. (2010), Increasing private capital flows to developing countries: The role of physical and financial infrastructure in 58 countries, 1970-2003. Applied Econometrics and International Development, 10-2, pp. 57-72, https://www.usc.gal/economet/reviews/aeid1025.pdf [Accessed 23.02.2021].

Lucas, R. E., (1990). Why doesn't capital flow from rich to poor countries? American Economic Review, 80(2), pp. 92-96, https://www.fep.up.pt/docentes/pcosme/s-e-1/13-AER-80-2.pdf [Accessed 23.02.2021].

Schularick, M., and Steger, T.M. (2008), The Lucas Paradox and the quality of institutions: Then and now. Diskussionsbeitrage, 2008/3, pp. 1-14, https://www.econstor.eu/bitstream/10419/28069/1/56007509X.PDF [Accessed 23.02.2021].

UNCTAD, (2020). Foreign direct investment: Inward and outward flows and stock, annual, https://unctadstat.unctad.org/wds/ReportFolders/reportFolders.aspx [Accessed 30.01.2020].

van Wijnbergen, S., and Franken, C. (2010), Private Capital Flows to Low Income Countries: Country-Specific Effects and the Lucas Paradox. Tinbergen Institute Discussion Paper, 10-003/2, pp. 1-41, https://www.econstor.eu/bitstream/10419/86853/1/10-003.pdf, [Accessed 23.02.2021].

World Bank, (2020a). World Development Indicators: GDP per capita, https://databank.worldbank.org/reports.aspx? source=2\&series=NY.GDP.PCAP.CD\&country $=[$ Accessed 31.01.2020].

World Bank, (2020b). Worldwide Governance Indicators: Institutional Quality, Regulatory Quality: Percentile Rank, https://databank.worldbank.org/Institutional-Quality/id/98e680fc [Accessed 31.01.2020].

World Bank, (2020c). World Development Indicators: Trade (\% of GDP), https://databank.worldbank.org/reports.aspx ? source=2\&series=NE.TRD. GNFS. ZS\& country $=$ [Accessed 31.01.2020].

World Bank, (2020d). Worldwide Governance Indicators: Institutional Quality, Government Effectiveness: Percentile Rank, January 31, 2020, https://databank.worldbank.org/Institutional-Quality/id/98e680fc [Accessed 31.01.2020].

World Bank, (2021). World Development Indicators: Labor force with advanced education, https://databank.worldbank.org/reports.aspx?source=2\&series=SE.XPD.TOTL.GD.ZS\&coun try=\# [Accessed 21.02.2021]. 